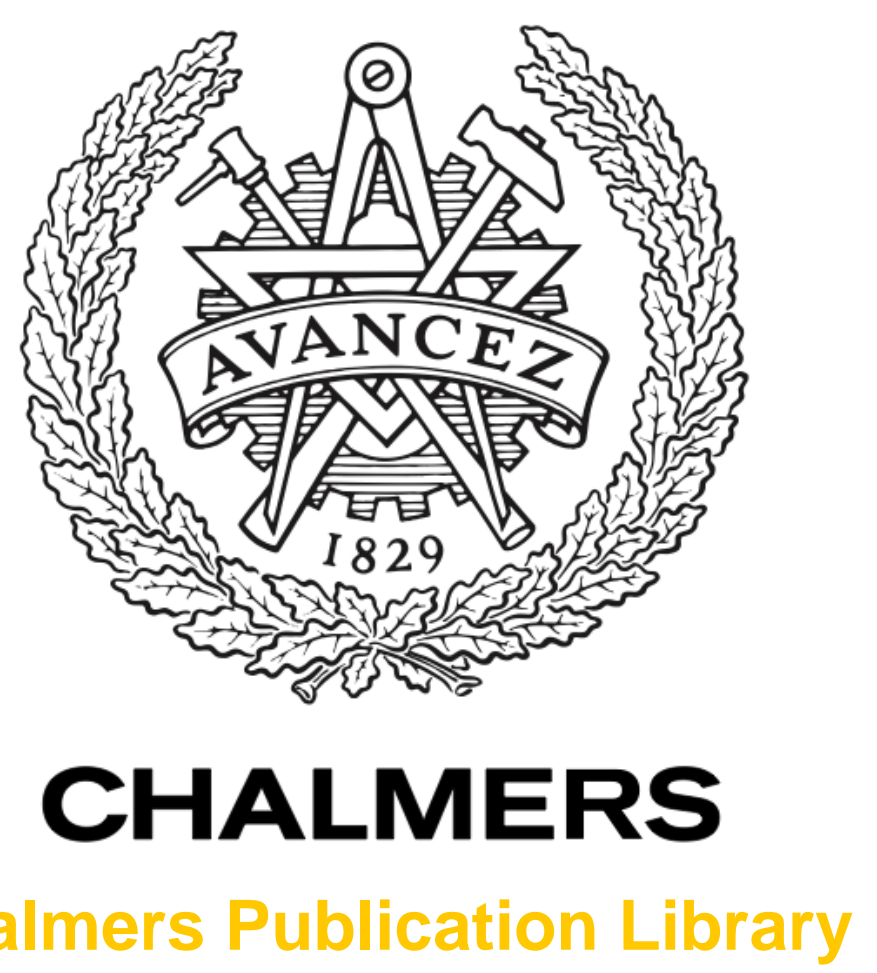

\title{
Gaseous emissions from co-combustion of sewage sludge and coal/wood in a fluidized bed
}

This document has been downloaded from Chalmers Publication Library (CPL). It is the author's version of a work that was accepted for publication in:

Fuel

Citation for the published paper:

Leckner, B. ; Åmand, L. ; Lücke, K. et al. (2004) "Gaseous emissions from co-combustion of sewage sludge and coal/wood in a fluidized bed". Fuel, vol. 83 pp. 477-486.

Downloaded from: http://publications.lib.chalmers.se/publication/5021

Notice: Changes introduced as a result of publishing processes such as copy-editing and formatting may not be reflected in this document. For a definitive version of this work, please refer to the published source. Please note that access to the published version might require a subscription. 


\title{
Gaseous emissions from co-combustion of sewage sludge and coal/wood in a fluidized bed
}

\author{
B. Leckner ${ }^{\mathrm{a}, *}$, L.-E. Åmand ${ }^{\mathrm{a}}$, K. Lücke ${ }^{\mathrm{b}, 1}$, J. Werther ${ }^{\mathrm{b}}$ \\ ${ }^{a}$ Department of Energy Conversion, Chalmers University of Technology, Göteborg SE-412 96, Sweden \\ ${ }^{\mathrm{b}}$ Verfahrenstechnik I, Technische Universität Hamburg-Harburg, Hamburg D-21071, Germany
}

Received 9 April 2003; revised 21 August 2003; accepted 21 August 2003; available online 16 September 2003

\begin{abstract}
Co-combustion of sewage sludge together with coal or wood has been investigated in two circulating fluidized bed (CFB) plants, a laboratory scale plant and a pilot scale $12 \mathrm{MW}_{\text {th }} \mathrm{CFB}$ boiler, in both of which the gas residence times are comparable to those in commercial plant. The investigation focuses on emissions of harmful gases from co-combustion compared to mono-combustion in CFB and the influence of air supply. The result shows that co-combustion can be carried out in CFB plant designed for the base fuel without exceeding EU or German emission limits for sludge energy fractions of less than $25 \%$, except for the chlorine emission that may have to be reduced by flue gas treatment. Although sewage sludge contains large quantities of nitrogen and sulfur, the beneficial properties of CFB lead to considerable reduction of nitrogen oxides, and only a few percent of the nitrogen was effectively converted to $\mathrm{NO}$ or $\mathrm{N}_{2} \mathrm{O}$. Sulfur can be captured by conventional limestone addition, but for wood as a base fuel this method is not as efficient as for coal.
\end{abstract}

(C) 2004 Elsevier Ltd. All rights reserved.

Keywords: Sludge; Co-combustion; Fludized bed; Emissions

\section{Introduction}

Sludge combustion has been practiced for decades in many types of combustors [1]. However, co-combustion of sludge with another fuel (the base fuel for which the plant was designed) has been suggested only recently. Moreover, the environmental regulations have become increasingly severe, and the addition of sludge to a combustion plant designed for a base fuel may require expensive modifications to meet the legislative conditions. The emissions of both heavy metals (including mercury) and harmful gases are of concern. The present work aims at investigating the feasibility of co-combustion of sewage sludge with base fuels, such as coal or biofuels (wood), with respect to the gaseous emissions, using fluidized bed combustion, a suitable combustion device for handling various types of fuel, with a good capability for $\mathrm{NO}_{x}$ reduction.

\footnotetext{
* Corresponding author. Tel.: +46-31-772-10-00; fax: +46-31-77235-92.

E-mail address: energy.conversion@entek.chalmers.se (B. Leckner).

${ }^{1}$ Present address: DOW Deutschland GmbH \& Co. OHG, Process Engineering, Building F2-2/116, P.O. Box 11 20, 21677 Stade.
}

\section{Experimental background}

The plants used were the $12 \mathrm{MW}_{\text {th }}$ circulating fluidized bed (CFB) combustor located at Chalmers Technical University (CTH) and the pilot scale CFB unit at the Technical University Hamburg-Harburg (TUHH). A schematic sketch of the plants is given in Fig. 1. The combustion chamber (1) of the CTH unit has a square cross-section of about $2.25 \mathrm{~m}^{2}$ and a height of $13.6 \mathrm{~m}$. Fuel is fed to the bottom of the combustion chamber through a fuel chute (8). The circulating solids are separated in the cyclone (2) and transported through the particle return leg (3), the loop seal (5), and the external heat exchanger (6) back into the combustion chamber. Primary combustion air (9) is supplied to the wind box (7) below the gas distributor, whereas secondary air may be added either into the combustion chamber (10) or downstream of the cyclone (11). The exit duct is refractory lined and serves as an afterburner chamber (12). The dimensions of the CTH unit are close to commercial scale, and the results obtained are transferable to industrial units. The pilot scale unit at TUHH consists of a cylindrical combustion chamber (1) with a diameter of $0.1 \mathrm{~m}$ (cross-section area $0.008 \mathrm{~m}^{2}$ ) and a total 


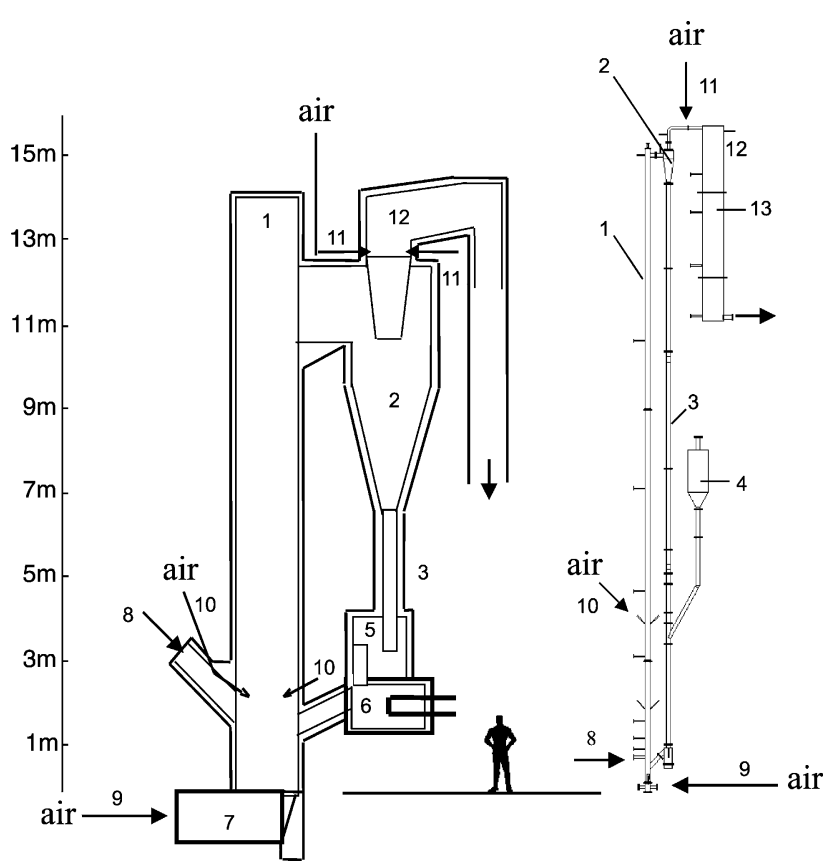

Fig. 1. The CFB test facilities at CTH in Göteborg (left) and at TUHH in Hamburg (right): (1) combustion chamber, (2) cyclone, (3) particle return line, (4) bed material hopper, (5) particle seal, (6) heat exchanger, (7) windbox, (8) fuel feed, (9) primary air supply, (10) secondary air addition into combustion chamber, (11) secondary air addition after cyclone, (12) after-burner chamber, and (13) probe for flue gas extraction.

height of $15 \mathrm{~m}$. The fuel is fed into the dense bed of the CFB via a screw feeder (8). The after-burner (12) has a diameter of $0.3 \mathrm{~m}$ and a length of $4.25 \mathrm{~m}$, giving a residence time of up to $8 \mathrm{~s}$. For emission measurements, gas was withdrawn from a sampling port (13) at half of the length of the afterburner, resulting in a total gas residence time of about $2.7 \mathrm{~s}$ under the operating conditions applied. Although this combustor is significantly smaller in diameter than the CTH boiler, it has been shown in a previous investigation [2] that the emissions are practically the same as those from the CTH boiler, if suitable similarity rules are obeyed in operation. The similarity criteria can be summarized by the following conditions that should be approximately the same in both units:

- bed material, fuel and additive

- gas residence time in the hot region

- fluidizing velocities

- riser pressure drop

- bed temperature

Both boilers are equipped with daily calibrated gas analysis systems for monitoring both local in-furnace and flue gas concentrations of $\mathrm{O}_{2}, \mathrm{CO}_{2}, \mathrm{CO}, \mathrm{SO}_{2}, \mathrm{NO}, \mathrm{NO}_{2}$, $\mathrm{N}_{2} \mathrm{O}, \mathrm{H}_{2} \mathrm{O}$, and $\mathrm{C}_{x} \mathrm{H}_{y}$. FTIR was used to detect precursors of the nitrogen oxide emissions, such as $\mathrm{NH}_{3}$ and $\mathrm{HCN}$.

The properties of the fuels are summarized in Table 1. The base fuels used in both plants were either Polish coal or wood pellets. Pellets were used to provide a homogeneous and well-defined fuel. The sludges were Swedish municipal sewage sludge (A), dried after digestion and burned in both plants, German (B) or Swedish (C) digested and mechanically de-watered municipal sewage sludges that could not be transported and therefore were used in the respective plants. The composition of the sludges is almost identical with high nitrogen and sulfur contents.

The operating conditions are given in Table 2. Similar conditions were maintained in the two plants, with some minor deviations. In the electrically supported TUHH plant, there was a slight fall in bed temperature along the height of the riser (average top and bottom temperatures are given in the table), whereas in the $\mathrm{CTH}$ boiler there was a slight increase of temperature with furnace height, but a decrease in the cyclone and in the after-burner chamber. The temperature decrease occurred because the cooling through the refractory was greater than the heat released by combustion (the exit temperature varies somewhat from case to case depending on

Table 1

Properties of the fuels investigated

\begin{tabular}{|c|c|c|c|c|c|}
\hline Fuel type & Coal & Wood (pellets) & Sewage sludge A dried & Sewage sludge B wet & Sewage sludge $\mathrm{C}$ wet \\
\hline \multicolumn{6}{|l|}{ Proximate analysis } \\
\hline Water (wt\%, raw) & 9.0 & 8.1 & 19.0 & 73.0 & 76.6 \\
\hline Ash (wt\%, dry) & 17.5 & 0.4 & 37.9 & 46.0 & 43.2 \\
\hline Volatiles (wt $\%$, daf) & 32.7 & 81.7 & 90.6 & 90.3 & 92.4 \\
\hline \multicolumn{6}{|l|}{ Ultimate (wt\%, daf) } \\
\hline $\mathrm{H}$ & 5.0 & 6.1 & 7.1 & 7.1 & 8 \\
\hline $\mathrm{O}$ & 7.7 & 43.6 & 30.6 & 33.2 & 33.9 \\
\hline $\mathrm{S}$ & 0.7 & 0.01 & 1.9 & 1.6 & 1.5 \\
\hline $\mathrm{N}$ & 1.6 & 0.12 & 7.11 & 6.05 & 6.9 \\
\hline $\mathrm{Cl}$ & 0.08 & 0.002 & 0.05 & 0.09 & 0.08 \\
\hline \multicolumn{6}{|c|}{ Lower heating value $(\mathrm{MJ} / \mathrm{kg})$} \\
\hline$H_{\mathrm{u}}$, daf & 33.4 & 18.8 & 20.9 & 19.9 & 23.9 \\
\hline
\end{tabular}

daf $=$ dry and ash free. 
Table 2

Operating conditions

\begin{tabular}{|c|c|c|c|c|c|c|c|}
\hline $\begin{array}{l}\text { Plant, base fuel, } \\
\text { added fuel }\end{array}$ & $\begin{array}{l}\text { TUHH, coal, } \\
\text { dried sludge }\end{array}$ & $\begin{array}{l}\text { TUHH, coal, } \\
\text { wood }\end{array}$ & $\begin{array}{l}\text { TUHH, wood, } \\
\text { dried sludge }\end{array}$ & $\begin{array}{l}\text { TUHH, coal, } \\
\text { wet sludge }\end{array}$ & $\begin{array}{l}\text { CTH, coal, } \\
\text { dried sludge }\end{array}$ & $\begin{array}{l}\text { CTH, wood, } \\
\text { dried sludge }\end{array}$ & $\begin{array}{l}\text { CTH, coal, } \\
\text { wet sludge }\end{array}$ \\
\hline $\begin{array}{l}\text { Riser temperature, } \\
\text { bottom, }{ }^{\circ} \mathrm{C}\end{array}$ & 860 & 860 & 860 & 850 & 841 & 841 & 843 \\
\hline Riser temperature, top, ${ }^{\circ} \mathrm{C}$ & 835 & 835 & 835 & 830 & 855 & 857 & 860 \\
\hline $\begin{array}{l}\text { Total pressure drop } \\
\text { of riser, mbar }\end{array}$ & 75 & 76 & 75 & 75 & 68 & 68 & 65 \\
\hline Molar ratio, $\mathrm{Ca} / \mathrm{S}$ & 2.3 & 2.3 & 2.3 & 2.3 & 2.3 & 1.9 & 3.0 \\
\hline Excess air ratio, $\lambda_{\text {total }}$ & 1.22 & 1.22 & 1.21 & 1.21 & 1.23 & 1.23 & 1.22 \\
\hline $\begin{array}{l}\text { Advanced air staging } \\
\text { Combustor air ratio, } \lambda_{\mathrm{c}}\end{array}$ & $1.0-1.23$ & $1.0-1.23$ & $1.0-1.23$ & $1.0-1.23$ & 1.05 & 1.03 & 1.03 \\
\hline
\end{tabular}

the amount of sludge addition). The combustors are equipped such that the data given in Table 2 (particularly the bed temperatures) could be maintained despite the large variations in fuel composition and heating value. The CTH boiler could run with an energy fraction of sludge up to about $50 \%$ for dried sludge and about $10 \%$ in the case of the wet sludge, whereas the electrically heated TUHH plant could run even higher sludge fractions. The calcium in the fuel ash clearly affects the $\mathrm{Ca} / \mathrm{S}$ ratio in the combustor, especially in the wood case before addition of sludge, but the ratios given are those of $\mathrm{Ca}$ added in the form of limestone. The difference between total excess air ratio and combustor or bottom bed air ratio is the air flow added in the after-burner or in the furnace during operation with advanced or normal air staging, respectively (this will be further explained below). Because of the different locations of air supply and of the gas produced by fuel moisture, the fluidization velocity in the upper part of the riser varies between 4.5 and $6 \mathrm{~m} / \mathrm{s}$ between the runs. This has not been found to essentially influence the results but is of course taken into account when evaluating gas concentrations.

The operation was stable for each condition and variations in the order of only a few percent were recorded. Each CTH test was conducted after a stabilization time of $8-10 \mathrm{~h}$ and with $12-16 \mathrm{~h}$ duration. At TUHH shorter times could be used, the duration of a test, including stabilization, being typically $16 \mathrm{~h}$.

\section{Influence of air staging on emissions}

Air staging is a well-known measure used for $\mathrm{NO}_{x^{-}}$ control. In conventional (normal) air staging both primary and secondary air are supplied to the riser (furnace) of the CFB boiler. The riser is therefore divided into two sections. In the first stage, below the secondary air injection, oxygenlean conditions favor the destruction of $\mathrm{NO}$ by high $\mathrm{CO}$ and char concentrations. Downstream of the secondary air injection port, in the second stage, an oxygen-rich atmosphere leads to burnout of carbon monoxide and other unreacted combustible gases. During advanced air staging, the second stage is located after the separation of the solid particles from the flue gas, while the whole riser is operated under near-stoichiometric conditions (Fig. 2). By this method, more air is supplied to the lower part of the combustion chamber than during normal staging. This increase in the amount of air to the bottom part is beneficial for sulfur capture with limestone. The oxygen is almost entirely consumed at the top of the riser section, and this has been proven to reduce $\mathrm{N}_{2} \mathrm{O}$ emissions. In addition, the $\mathrm{NO}$ emission decreases. The effect of advanced air staging on emissions of $\mathrm{SO}_{2}, \mathrm{~N}_{2} \mathrm{O}$, NO, and $\mathrm{CO}$ was first investigated for coal combustion [3].

The total excess air was always about $20 \%$. Typical results from operation with single fuels (mono-combustion) for various riser excess air ratios are shown in Fig 3. Three cases should be noted: (1) normal staging (presented for comparison at the right-hand axes of the diagrams and indicated by $\mathrm{N}),(2)$ no-staging, all air is supplied to the bottom of the riser and the primary air ratio is identical to the total air ratio 1.2 , and (3) advanced staging with an optimum primary air ratio

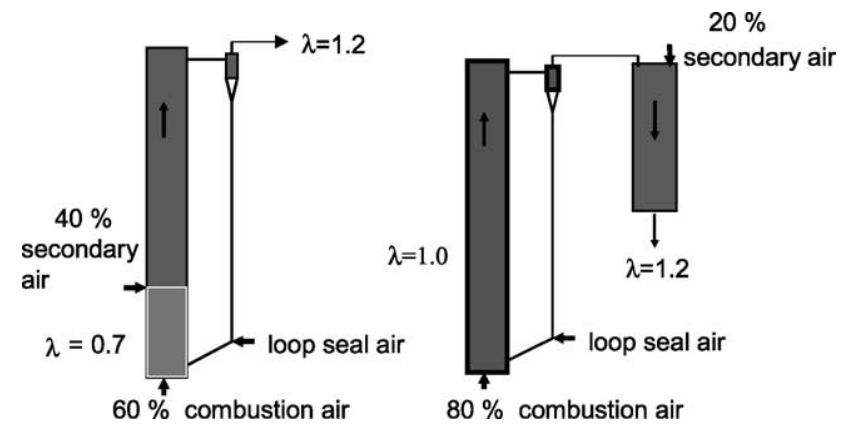

Fig. 2. Comparison of normal (left figure) and advanced air staging (right figure). ( $\lambda$ is air ratio.) 

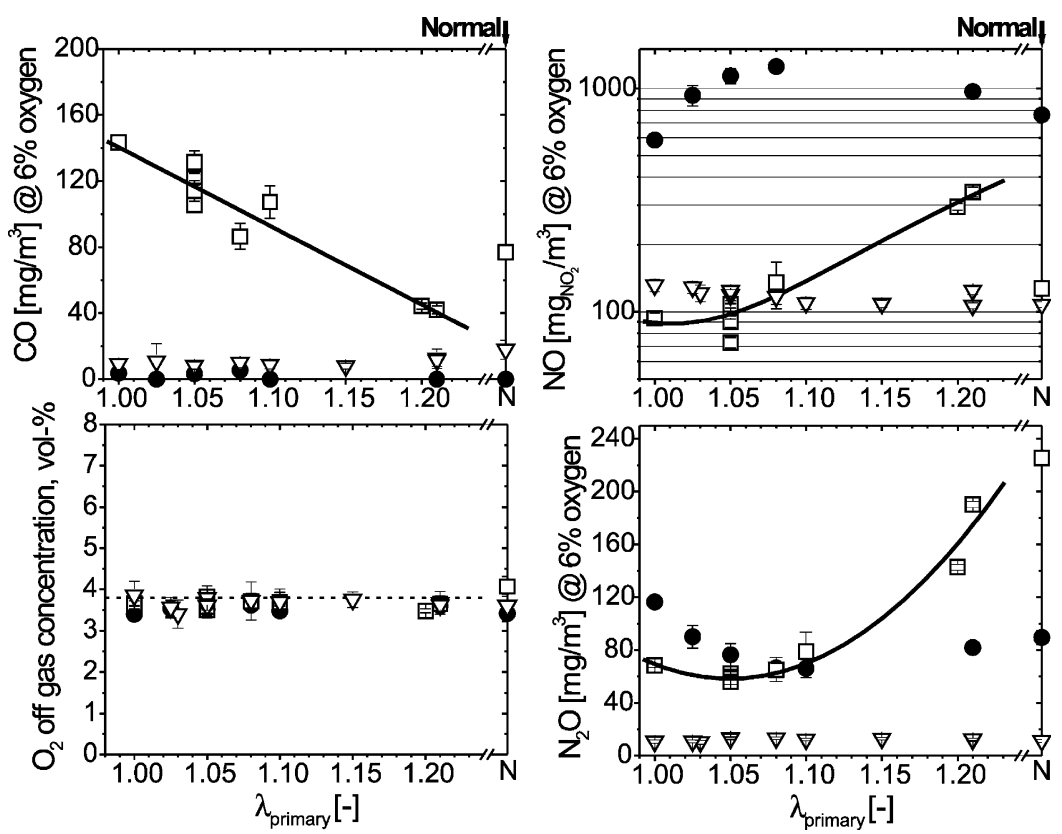

Fig. 3. Influence of combustor air ratio on $\mathrm{CO}$ and $\mathrm{NO}$ emissions during mono-combustion of coal, sludge or wood at a total air ratio of 1.2 . TUHH test facility. ( $\square$, coal; $\bullet$, dried sewage sludge A; and $\nabla$, wood.) N means normal staging with secondary air through supply nozzles 10 in Fig. 1.

chosen to be 1.05 (which is used in all following cases involving advanced air staging, if not otherwise stated).

The CO emission for coal combustion falls with increasing air supply to the furnace, whereas the highvolatile fuels (wood and sludge) always yield a low CO emission, as expected in a well-designed combustor (sufficient oxygen, temperature, and time). The higher $\mathrm{CO}$ emission related to coal is caused by additional $\mathrm{CO}$ production from char combustion. During advanced staging with coal, the CO concentration is higher than for normal staging but still low. The rise in CO is accompanied by an increase in char concentration in the ash (loss of combustibles), and attention has to be paid to char burnup, that is, sufficiently high temperatures should be maintained in the exit region. The $\mathrm{NO}$ and $\mathrm{N}_{2} \mathrm{O}$ emissions from coal behave as expected [3], and advanced staging leads to a substantial improvement compared to normal staging with an optimum close to stoichiometric conditions. The corresponding emissions from wood and sludge, however, do not show any clear trends in relation to the distribution of air supply. The NO emission from sludge may be very high, whereas the one from wood is in the same order as from coal. The similarity of the NO emissions from coal and wood is a consequence of the combination of the nitrogen content of the fuels and their capacity for NO reduction, as will be discussed below. The $\mathrm{N}_{2} \mathrm{O}$ emission is, relatively, low for sludge and hardly noticeable for wood.

The trends observed during mono-combustion are reflected also in co-combustion: in the practically important cases with moderate amounts of sludge (say, an energy fraction of less than 25\%) the properties of the base fuels dominate the emission picture. Naturally, as the extreme case of pure sludge is approached, the properties of sludge become dominant. Especially important is the impact of the arrangement of air supply, illustrated in Fig. 4 by comparison between the extreme cases: advanced air staging and no-air staging. For coal, there is a substantial difference between the two cases (in agreement with Fig. 3). Only at high sludge content do the two cases coincide. For wood/dried sludge there is no influence of air supply, just as in the case of pure sludge. As observed previously [4], during coal combustion the char concentration in the bed is in an order of magnitude higher than during wood or sludge combustion. Char is known to contribute to reduction of NO (and to some extent also to that of $\mathrm{N}_{2} \mathrm{O}$ ). When the air supply is changed, the char concentration is affected (the more oxygen, the less char in the bed), but when the char concentration is small, a change in char concentration, caused by, for instance, a change between advanced and no-staging, is too small to be noticeable in form of a change in NO emission. This explains also cocombustion of coal and wood, where the emission reaches around $100 \mathrm{mg} / \mathrm{m}^{3}$ for pure wood, while the corresponding value for pure sludge is about $1000 \mathrm{mg} / \mathrm{m}^{3}$ due to the different nitrogen contents in wood and sludge. Although high emissions can be attained, normally only a few percent of the fuel nitrogen is converted to $\mathrm{NO}$ or $\mathrm{N}_{2} \mathrm{O}$. Fig. 4 also shows the case of wet sludge co-combusted with coal. At present, the reason for the falling trend (compared to the rising trend for dried sludge) with increasing amount of sludge is unknown.

\section{Emissions compared to emission limits}

The resulting emissions from co-combustion of sludge with wood or coal are presented in Figs. 5-8 as a function of the energy fraction of sludge. A comparison is made with 

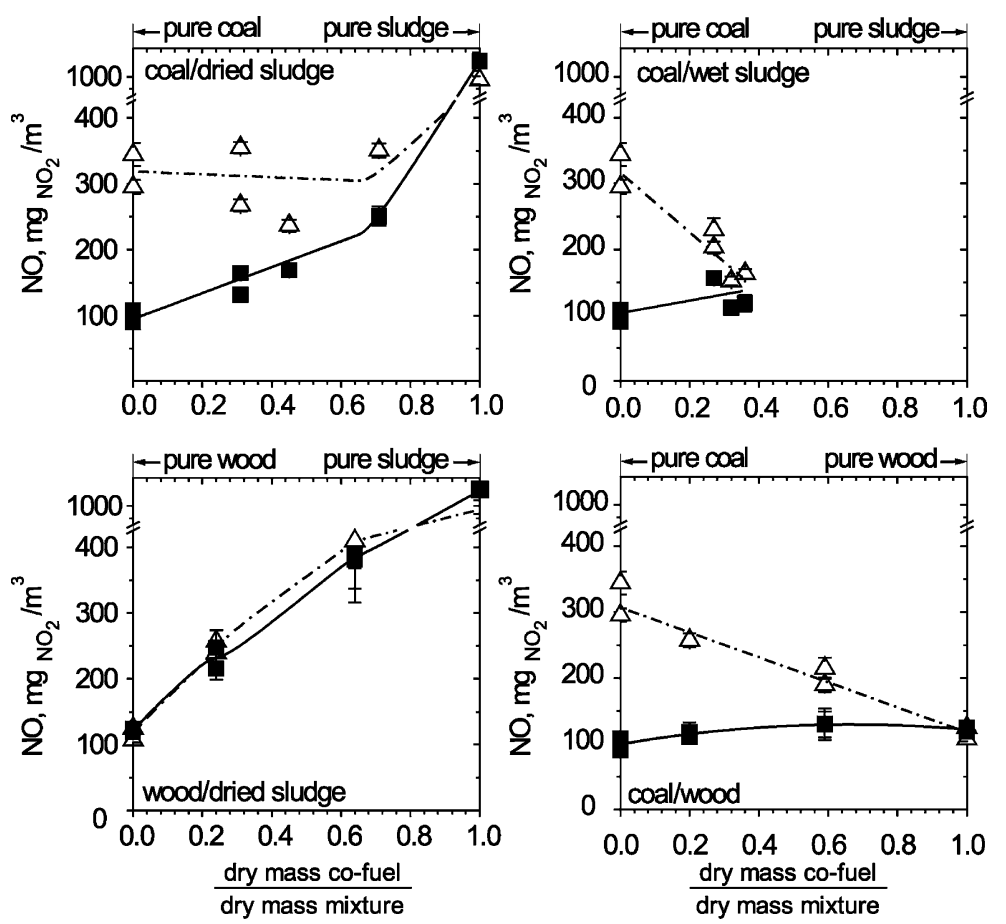

Fig. 4. Comparison of advanced staging $(\square)$ and no-staging $(\triangle)$ during co-combustion in the TUHH combustor. (Concentrations in mg/m ${ }^{3}$ under standard conditions, based on $6 \mathrm{vol} \% \mathrm{O}_{2}$ and dry basis.) The vertical scale is shortened.

the emission limits according to a recent EU directive [5] and to existing German legislation [6,7]. The emissions are expressed in $\mathrm{mg} / \mathrm{m}^{3}$ under standard conditions, based on an $\mathrm{O}_{2}$ concentration that is interpolated between the values for waste incinerators $(11 \%)$ and power plants $(6 \%)$. The structure of the diagrams depends on the properties of the fuels. The emission limit (EL) for a pollutant $i$ in the exhaust gas, resulting from co-incineration of waste, is calculated as follows [5]:

$\mathrm{EL}_{i, \text { mix }}=\frac{V_{\mathrm{w}} \mathrm{EL}_{i, \mathrm{w}}+V_{\mathrm{bf}} \mathrm{EL}_{i, \mathrm{bf}}}{V_{\mathrm{w}}+V_{\mathrm{bf}}}$

where

$V_{\mathrm{w}} \quad$ exhaust gas volume resulting from combustion of waste only, $\mathrm{m}^{3} / \mathrm{h}$, at standard temperature and
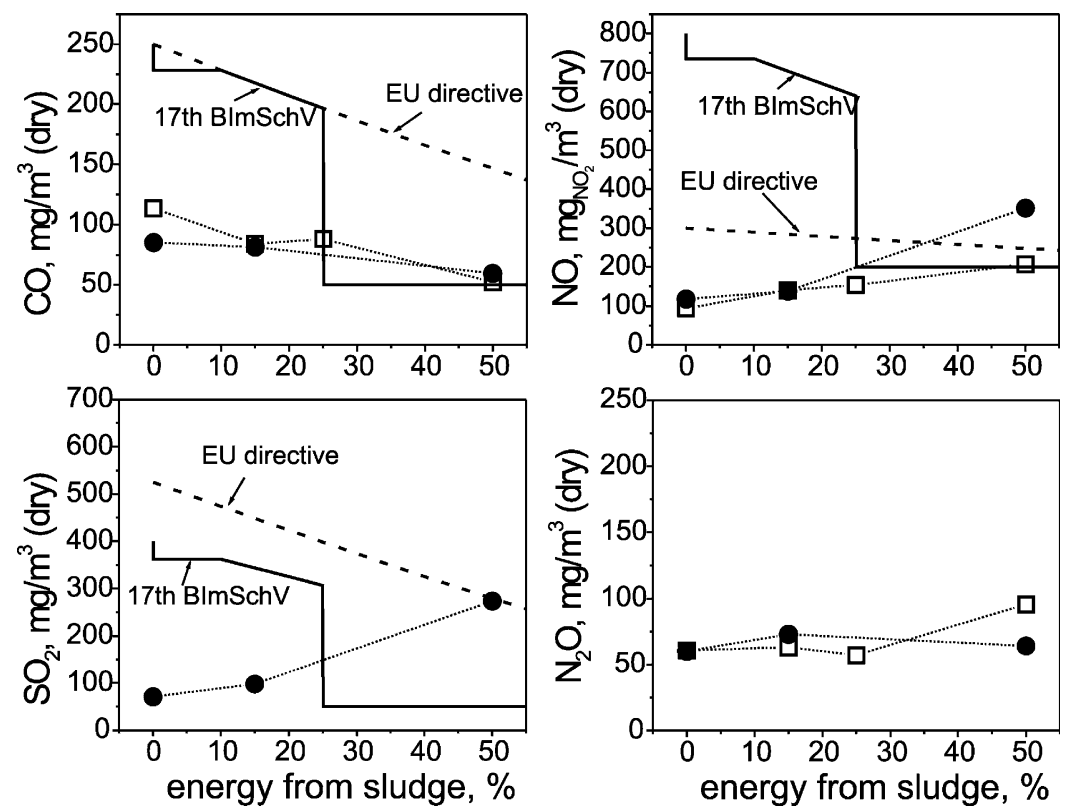

Fig. 5. Emissions from co-combustion of dried sewage sludge A with coal. Comparison between plants $(\bullet$, CTH and $\square$, TUHH) and with legal limits. Advanced staging. The measured data have been evaluated at the oxygen levels required by the EU directive. The corresponding points evaluated according to German standards are only slightly different. 

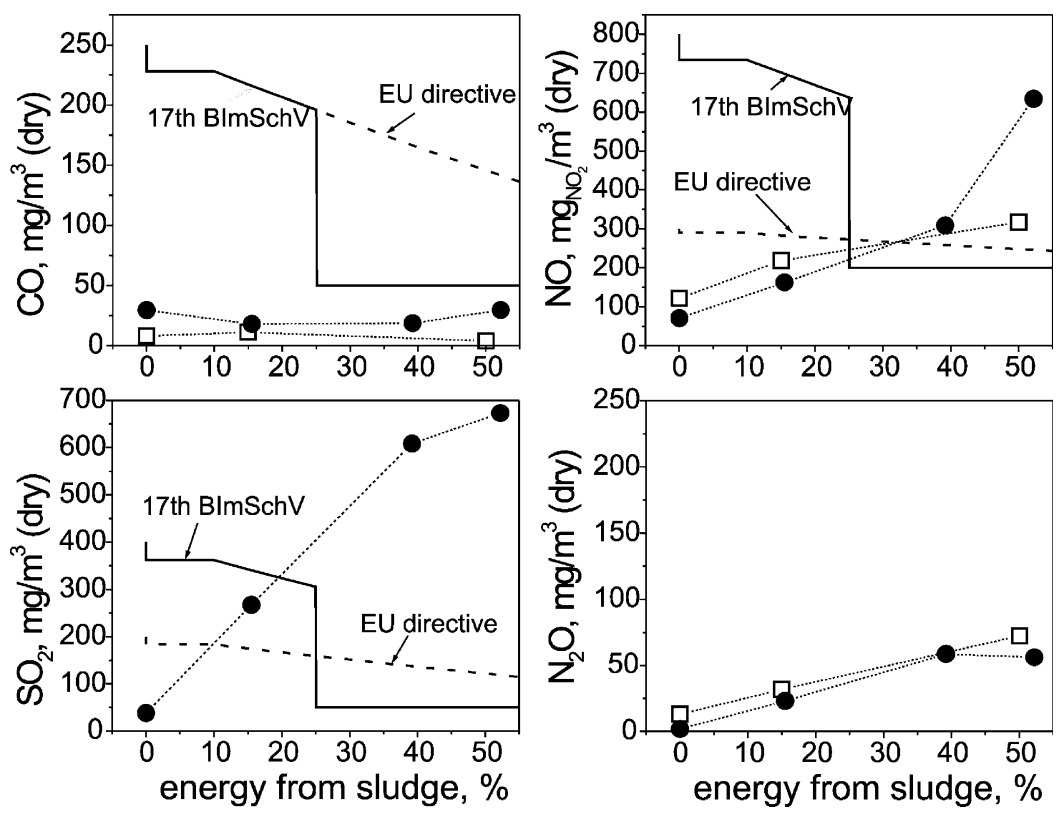

Fig. 6. Emissions from co-combustion of dried sewage sludge A with wood. Comparison between plants $(\bullet$, CTH and $\square$, TUHH) and with legal limits. Advanced staging. The measured data have been evaluated at the oxygen levels required by the EU directive. The corresponding points evaluated according to German standards are only slightly different.

pressure and operating conditions prevailing during co-combustion

$V_{\mathrm{bf}} \quad$ exhaust gas volume resulting from combustion of the base fuel in the normal plant, $\mathrm{m}^{3} / \mathrm{h}$, at standard temperature and pressure and operating conditions prevailing during co-combustion

$\mathrm{EL}_{i, \mathrm{w}} \quad$ emission limit for pollutant $i$ for plants intended to incinerate waste only, $\mathrm{mg} / \mathrm{m}^{3}$

$\mathrm{EL}_{i, \mathrm{bf}} \quad$ emission limit for pollutant $i$ for plants in certain industrial sectors (e.g. for power plants), $\mathrm{mg} / \mathrm{m}^{3}$
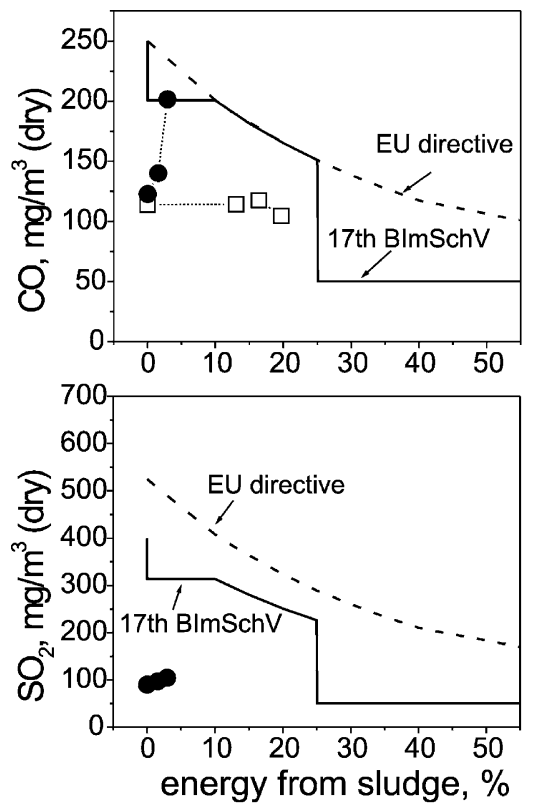

Since $\mathrm{EL}_{i, \mathrm{w}}$ and $\mathrm{EL}_{i, \mathrm{bf}}$ are related to different oxygen concentrations for waste incinerators or for power plants, a mixed reference oxygen concentration has to be determined:

$C_{\mathrm{O}_{2}, \text { mix }}=\frac{V_{\mathrm{w}} C_{\mathrm{O}_{2}, \mathrm{w}}+V_{\mathrm{bf}} C_{\mathrm{O}_{2}, \mathrm{bf}}}{V_{\mathrm{w}}+V_{\mathrm{bf}}}$

where $C_{\mathrm{O}_{2}, \mathrm{w}}$ and $C_{\mathrm{O}_{2}, \mathrm{bf}}$ are standard oxygen concentrations in the off gas of waste incineration plants and power plants, respectively. The gas concentration of pollutant $i$, measured
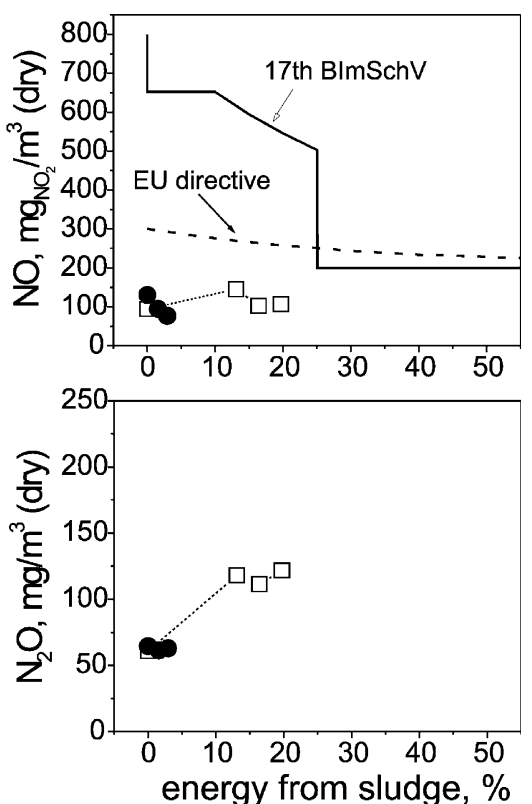

Fig. 7. Emissions from co-combustion of wet sewage sludge B and C with coal. Comparison between plants $(\bullet$, CTH, and $\square$, TUHH) and with legal limits. Advanced staging. The measured data have been evaluated at the oxygen levels required by the EU directive. The corresponding points evaluated according to German standards are only slightly different. 


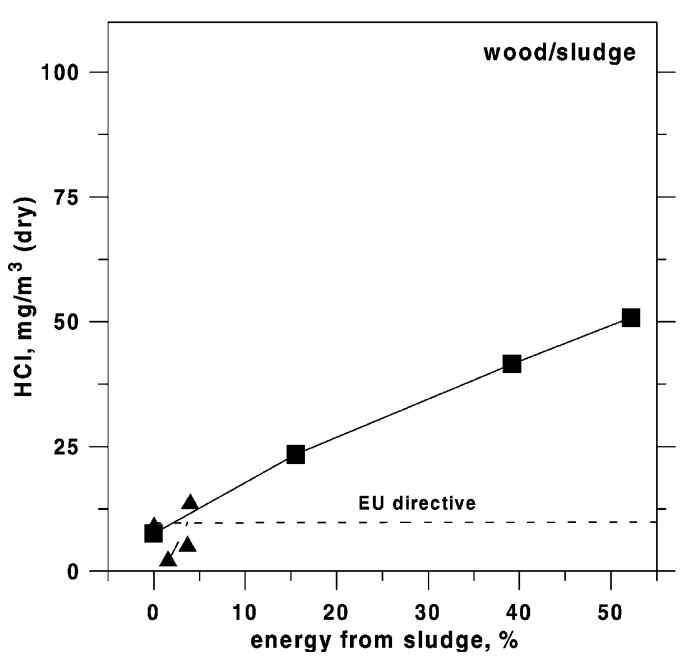

Fig. 8. Emissions of $\mathrm{HCl}$ from co-combustion of wet $(\boldsymbol{\Lambda}, \mathrm{C})$ or dry

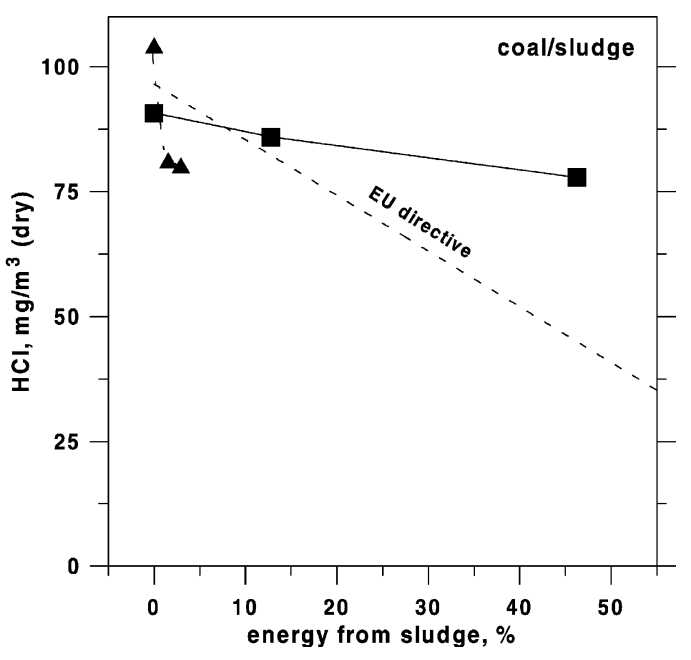

A) sludge with wood or coal in the $\mathrm{CTH}$ boiler. in the chimney of the power plant at a particular air ratio, has to be recalculated to the mixed reference oxygen concentration in order to compare with the legal emission limits

$C_{i @ \mathrm{O}_{2}, \text { mix }}=\frac{21-C_{\mathrm{O}_{2} \text {,mix }}}{21-C_{\mathrm{O}_{2} \text {,meas }}} C_{i, \text { meas }}$

The legal limits are kept as long as $C_{i @ \mathrm{O}_{2} \text {,mix }} \leq \mathrm{EL}_{i \text {,mix }}$ holds.

The emission limits and the measured emissions are related to the fraction of waste energy-including auxiliary fuel to sustain the waste incineration-to total resulting energy supply, defined as:

$\xi_{\mathrm{w}}=\frac{\left(\dot{m}_{\mathrm{w}} H_{\mathrm{u}, \mathrm{w}}+\dot{m}_{\mathrm{aux}} H_{\mathrm{u}, \mathrm{aux}}\right)}{\left(\dot{m}_{\mathrm{w}} H_{\mathrm{u}, \mathrm{w}}+\dot{m}_{\mathrm{aux}} H_{\mathrm{u}, \mathrm{aux}}\right)+\dot{m}_{\mathrm{bf}} H_{\mathrm{u}, \mathrm{bf}}}$

where

$\dot{m}_{\mathrm{w}} \quad$ feed rate of waste, $\mathrm{kg} / \mathrm{h}$

$\dot{m}_{\text {aux }}$ feed rate of auxiliary fuel to sustain waste combustion under mono-combustion conditions, $\mathrm{kg} / \mathrm{h}$

$\dot{m}_{\mathrm{bf}} \quad$ feed rate of base fuel, $\mathrm{kg} / \mathrm{h}$

$H_{\mathrm{u}, \mathrm{w}}, H_{\mathrm{u}, \mathrm{aux}}, H_{\mathrm{u}, \mathrm{bf}}$ lower calorific values of waste, auxiliary fuel, and base fuel, respectively, for raw conditions, $\mathrm{MJ} / \mathrm{kg}$

The definition of auxiliary fuel is ambiguous in the standards, and although this may be an important issue for the application of the standards, it is not needed for the present comparison and here $\dot{m}_{\text {aux }}$ is equal to zero.

The EU standard in Figs. 5-8 moves smoothly from the conditions of power plants to those of waste incinerators. The German standard makes this transition in the form of a jump at $25 \%$ waste. The emissions from the two test plants are similar and show gradual changes due to the addition of sludge. In general, the emissions are lower than the emission standards for sludge fractions of less than $25 \%$, which is an acceptable result, as it can be assumed that only minor fractions of additional fuel are of practical interest. A few comments can be made.

- The emission limit is exceeded for lower values than $25 \%$ sludge in the case of $\mathrm{SO}_{2}$ emission during cocombustion of sludge and wood. Firstly, sulfur capture by limestone seems to be less efficient for highvolatile fuel than for coal. Secondly, and more serious, the EU emission limit for $\mathrm{SO}_{2}$ emission from biofuels is much lower than that for coal, and the emission limit may be exceeded even if sulfur capture is enhanced by adding more limestone.

- There is no emission limit for $\mathrm{N}_{2} \mathrm{O}$. However, $\mathrm{N}_{2} \mathrm{O}$ is a globally pollutant gas, and efforts should be made to reduce the emission. Fortunately, the emission of $\mathrm{N}_{2} \mathrm{O}$ from sludge combustion is not high.

- The emissions from wet sludge are similar to those of dried sludge with the exception of a slightly enhanced emission of $\mathrm{N}_{2} \mathrm{O}$.

The emission of chlorine takes the form of hydrogen chloride. The measured emissions from the CTH boiler are shown in Fig. 8. They reflect the chlorine contents of the fuels (Table 1). The absorption by the alkali constituents in the ash or by limestone does not have a notable impact; it is small in comparison with the error bounds of the data (The chlorine concentration is just given by one significant digit in Table 1.). The EU standard for mono-combustion of waste is $10 \mathrm{mg} / \mathrm{m}^{3}$, whereas at present there is no definite standard for a mono-fired power station in most countries: the value that is actually measured for the regular fuel, e.g. coal, is sometimes applied. Using Eq. (1) with the measured value for mono-combustion and $10 \mathrm{mg} / \mathrm{m}^{3}$ for wastes, it becomes evident from Fig. 8 that co-combustion with sludge (or other chlorine-containing waste fuels) is hardly possible without flue gas treatment. However, in Germany there is a plan to introduce an exception in current 
legislation for fluidized bed combustors with a limiting value of $100 \mathrm{mg} \mathrm{HCl} / \mathrm{Nm}^{3}$, independent of the energy fraction of waste.

\section{Comparison with a commercial plant}

Regarding the applicability of these results to a commercial plant it should be emphasized that approximate similarity rules [2] were applied, and indeed, Figs. 5-7 show that the emissions from the two plants are quite similar. The different width of the combustors may have some impact on mixing of fuel and air as has been shown previously where a major difference in concentration profiles arose from the horizontal mixing of secondary air in the riser. This feature is avoided in the present tests, in which the air is introduced from the bottom of the risers and in the strongly swirling flow downstream of the cyclones.

For similar fuel and operation conditions the gas residence time is a remaining important parameter. Therefore, the gas residence times of the two plants have been compared with each other in Table 3 and also with a large commercial CFB boiler. Despite the tremendous difference in size (volume) of the three combustors, the gas residence times in the combustion chamber (riser) have the same order of magnitude. The principal difference between the plants is in the size of the cyclones. Because of the large cross-section of the furnace, the cyclone of the commercial boiler is very large compared with that of the narrow laboratory combustor. However, the after-burner chambers located downstream of the cyclones provide the residence time needed to make the smaller plants similar to the larger one. It was verified by measurements that there is a considerable combustion, including formation and destruction of pollutants, in these after-burners. In total, the minimum gas residence time in the high temperature

Table 3

Gas residence times in CFB units of different scales

\begin{tabular}{llll}
\hline & TUHH & CTH & Flensburg \\
\hline Volume of combustion chamber, $\mathrm{m}^{3}$ & 0.13 & 31.4 & 590 \\
Volume of cyclone including the & 0.024 & 12.4 & 490 \\
entry duct, $\mathrm{m}^{3}$ & & & \\
Volume of after-burner chamber, $\mathrm{m}^{3}$ & 0.13 & 10.7 & - \\
Gas residence time in & 2.6 & 2.2 & 3.8 \\
combustion chamber, $\tau_{\mathrm{cc}}, \mathrm{s}$ & & & \\
Gas residence time in cyclone, $\tau_{\mathrm{c}}, \mathrm{s}$ & 0.5 & 0.9 & 3.2 \\
Gas residence time in & 2.7 & 0.8 & - \\
after-burner chamber, $\tau_{\mathrm{ac}}, \mathrm{s}$ & & & \\
Gas residence time in burn-out zone, & 3.2 & 1.6 & 3.2 \\
$\tau_{\mathrm{c}}+\tau_{\mathrm{ac}}, \mathrm{s}$ & & & \\
Ratio of gas residence times & & & \\
$\tau_{\mathrm{c}} / \tau_{\mathrm{cc}}$ & 0.2 & 0.4 & 0.8 \\
$\tau_{\mathrm{c}}+\tau_{\mathrm{ac}} / \tau_{\mathrm{cc}}$ & 1.2 & 0.7 & 0.8 \\
\hline
\end{tabular}

part of the combustors $\left(800-900{ }^{\circ} \mathrm{C}\right.$ ) is around $4-6 \mathrm{~s}$ (Table 3). Although it has not been verified that the progress of combustion in the almost particle-free space of the after-burner is comparable to that in the cyclone, it is likely, because gases and particles are separated from each other inside the cyclone and interaction should not greatly affect gas phase reactions. In conclusion, it is reasonable to believe that the results from the two combustors used are representative also for large scale equipment.

The declining sulfur capture with increasing sludge fraction and during co-combustion with wood, seen in Figs 5-7, is similar to what has been observed before with high-volatile fuels. In the case of co-combustion with sludge the sulfur capture efficiency can have been further reduced by phosphorous competing with sulfur dioxide for calcium oxide, forming calcium phosphate instead of calcium sulfate.

\section{Summary of results and conclusions}

Dried sewage sludge can be handled together with the base fuels without any technical problems, but if the moisture content exceeds $10 \%$ the sludge is difficult to store for longer periods because of odors and biological activity that increases the temperature and reduces the calorific value. Co-combustion with dried sludge worked well, using the conventional fuel feed system, and only small differences from the over-all performance of the base fuels were observed, despite fractions of added fuel of up to $50 \%$ energy. A necessary condition is that the ash handling system of the plant can receive the increased ash flow resulting from the sludge. Moreover, fly ash from sludge combustion is stickier than ash from coal or wood.

With coal and wood as base fuels German and EU emission limits for $\mathrm{CO}, \mathrm{NO}_{x}$, and $\mathrm{SO}_{2}$ were not exceeded for energy fractions of additional fuel of less than $25 \%$. To fulfill the extremely low EU regulation for $\mathrm{SO}_{2}$ emission from co-combustion with wood, high limestone addition is needed.

The emission behavior of the base fuel plays a dominant role, particularly for energy fractions of additional fuel of less than $25 \%$.

Sewage sludge contains large quantities of nitrogen, and high emissions of NO may occur, especially during mono-combustion. However, the reduction in a $\mathrm{CFB}$ combustor is also high, particularly in the presence of char, and emissions are only moderate for waste energy fractions of less than 25\%; the conversion of fuel nitrogen to NO was only a few percent. Also the conversion to $\mathrm{N}_{2} \mathrm{O}$ was small.

It was found that air staging in CFB is not important for control of emissions from fuels with a high-volatile content, such as wood or sludge. The reason can be that 
char plays a dominant role for reduction of $\mathrm{NO}$ as well as for $\mathrm{N}_{2} \mathrm{O}$ in the combustion chamber, and the char content in the bed is small during combustion of fuels with a small content of fixed carbon. The oxygen concentration in the bed affects the char concentration, but with a small char concentration in the bed a change in the char concentration does not play a great role for NO reduction.

Both base fuels perform well. Only minor differences have been identified: (1) reduction of NO is better with coal than with wood, (2) $\mathrm{CO}$ emissions are lower with wood, (3) $\mathrm{N}_{2} \mathrm{O}$ emissions are low with wood compared to coal, but the emissions in the two cases become more equal when the fraction of sludge increases, and (4) the weak point of wood is that sulfur capture with limestone is slightly less efficient than with coal as base fuel.

A few tests were made with mechanically de-watered sludge, wet sludge. Wet sludge performed similar to dried sludge with respect to $\mathrm{NO}$ emission, but the $\mathrm{N}_{2} \mathrm{O}$ emissions were slightly higher.

Due to mixing limitations, high-volatile fuels often give rise to high concentrations of unburned gases in the upper regions of a CFB riser. This was the case even in the narrow TUHH combustor, also during combustion of coal, and of course the effect is present in the wider CTH boiler. When the gases enter the cyclone, mixing is improved and the gaseous combustion is enhanced. Burnout is achieved if the gas residence time is sufficient. After extension of the combustion space with the after-burner combustion chamber, the present plants attained gas residence times that were in the same order as those in a large commercial CFB boiler. The afterburner was also utilized for late addition of secondary air, applying the advanced staging method. There was a strong reduction of the concentration of $\mathrm{CO}$ (representing combustible volatiles) downstream of the main combustion chamber. This was noted also for $\mathrm{NO}$, but at least for coal with addition of sludge, unexpectedly, the $\mathrm{N}_{2} \mathrm{O}$ concentration rose in the afterburner. In general, however, the conclusion is that a satisfactory pollutant reduction and burnout was achieved after a gas residence time of 4-6s from the fuel inlet.

The progress of combustion is quite similar in the two research plants, especially as the air is supplied to the combustion chamber through the bottom section, and secondary air is only added downstream of the riser where the mixing is quite intensive (because of the intense swirl created by the cyclone). Therefore, there were no 'macroscopic' mixing differences like those observed in the case of normal staging, when the mixing is almost instantaneous in the narrow TUHH reactor but only gradual in the CTH boiler. Most oxygen is consumed in the bottom of the combustion chambers, and consequently most combustion takes place there. The minor differences in the progress of combustion in the two combustion chambers were evened out in the cyclones and the resulting emissions did not differ much. There was only a small influence of sludge addition on the combustion conditions, at the same time as a clear effect was seen on the concentrations of nitrogen oxides.

Sewage sludge contains sulfur, to a large extent arising from conversion of sulfur-containing proteins, but some may remain from the precipitation agent used in the sludge treatment process, especially if digestion is applied. The sulfur content of the presently investigated sewage sludge was twice as high as that of the coal (Table 1). Sulfur cleaning is necessary. In case of cocombustion with coal in CFB this does not cause any problem because the plant is most likely equipped for sulfur removal by limestone, and the additional sulfur from the sludge is just a marginal increase in the sulfur supply, handled with a likewise marginal increase in limestone feed. In a wood fired boiler, on the other hand, there is no equipment for sulfur removal, and the sulfur has to be removed from the sludge prior to combustion or by installation of sulfur cleaning equipment. Sulfur capture with limestone is the classical method in fluidized bed combustion. Addition of hydrated lime prior to the filter is another suitable method that also captures $\mathrm{HCl}$. This method can be used also with wood/ sludge, but it was found to be slightly less efficient for these fuels than with coal.

Wastes with low heating value (such as, for instance, wet sewage sludge) may need an auxiliary fuel to be burned. It is not evident how to treat such an auxiliary fuel with respect to emission regulations. In the present work such problems have been avoided by representing the emissions as a function of energy fraction without considering an auxiliary fuel.

Co-combustion that results in higher chlorine emissions than the EU-regulation $\left(10 \mathrm{mg} / \mathrm{m}^{3}\right)$ may require application of some chlorine removal method, irrespective of the degree of co-combustion, at least in most EU countries. Removal of chlorine can be achieved in pulverized fuel boilers, which are often equipped with special cleaning devices like scrubbers, etc. Even in fluidized bed (and other) boilers with bag filters chlorine can be simply removed from the gas by injection of hydrated lime in the flue gas path.

\section{Acknowledgements}

This work was funded by the German Boiler Owners' Association, VGB, and the research organization of the Swedish energy industry, Värmeforsk AB. Additional support was received from the Swedish Energy Administration (STEM) and from the Swedish organization of waste treatment plants, VA-forsk. The practical 
performance of the tests at the CTH boiler was carried out with heavy support from the operating staff of Akademiska Hus $\mathrm{AB}$ and researchers belonging to the Department of Energy Conversion, which is herewith gratefully acknowledged.

\section{References}

[1] Werther J, Ogada T. Sewage sludge combustion. Prog Energy Combust Sci 1999;25:55-116.

[2] Knöbig T, Werther J, Amand L-E, Leckner B. Comparison of large- and small-scale circulating fluidized bed combustors with respect to pollutant formation and reduction for different fuels. Fuel 1998;77: $1635-42$.
[3] Lyngfelt A, Åmand L-E, Leckner B. Reversed air staging—a method for reduction of $\mathrm{N}_{2} \mathrm{O}$ emissions from fluidized bed combustion of coal. Fuel 1998;77:953-9.

[4] Leckner B, Karlsson M. Gaseous emissions from circulating fluidized bed combustion of wood. Biomass Bioenergy 1993;4:379-89.

[5] Directive 2000/76/EC of the European Parliament and of the Council of 4 December 2000 on the incineration of waste, Off J Eur Commun 2000;L 332/91.

[6] Dreizehnte Verordnung zur Durchführung des Bundes-Immissionsschutzgesetzes (Verordnung über Großfeuerungsanlagen-13. BImSchV) vom 22.06.1983, BGB1. I S. 719.

[7] Siebzehnte Verordnung zur Durchführung des Bundes-Immissionsschutzgesetzes (Verordnung über Verbrennungsanlagen für Abfälle und ähnliche brennbare Stoffe-17. BImSchV) vom 23.11.1990, BGB1. I S. 2545, ber. S. 2832, zuletzt geändert am 23.02.1999, BGB1. I S. 186. 